filaments as the lophophore is coiled into dorsally instead of ventrally directed spirals. Thus on the grounds of functional necessity for an efficient filter feeding current-system the recent inarticulate Discinisca should possess an exhalant system. The filaments in such a system could be arranged as in fig. 3. The filaments of the proximal part of the lophophore flexed ventrally to touch the anterior body wall, forming a tunnel to conduct that part of the exhalant water, which has passed through these filaments to the main exhalant chamber in the spirals.

Cases when scientific method can be applied rigorously in palaeontology are perhaps rather rare, but this would appear to be one such case. The theoretical conclusion that Discinisca possesses an exhalant system is capable of being verified by direct observation on the living animal when material becomes available. If it does possess an exhalant system it will strengthen the value of Rudwick's hypothesis for fossil spire bearers with spirolophous lophophores. It will not of course prove that fossil spire bearers had spirolophes rather than deuterolophes.

\title{
REFERENCES
}

Blochmann, F., 1900. Untersuchung über den Bau der Brachiopoden. Zweiter Teil. Die Anatomie von Discinisca lamellosa (Broderip) und Lingula anatina Brugière. 69-124. Taf. vii-xix. Jena.

Rudwick, M. J. S., 1960. The feeding Mechanisms of Spire-bearing Fossil Brachiopods. Geol. Mag., xcvii, 369-383.

Williams, A., 1960. Feeding Mechanisms of Spire-bearing Brachiopods. Geol. Mag. xcvii, 514-516.

Department of Geology,

A. J. ROWELL.

UNIVERSITY OF NOTTINGHAM.

18th April, 1961.

\section{ORIGIN OF ALBITE PORPHYROBLASTS}

SiR,--In his paper on the "Origin of Albite Porphyroblasts in Rocks of the Ben More-Am-Binnein Area ", in the January-February issue (Geol. Mag., 98, 41-55), Dr. Jones has misrepresented, to an extent worth correction, the conclusions which I drew from work on albite gneisses in this area and elsewhere in the Dalradian some time ago (Trendall, 1953).

First, a minor point on page 43: Dr. Jones is confusing my views with Reynolds" in the sentence "The origin of the porphyroblasts was considered by Trendall to be due to a soda metasomatism, possibly from a trondhjemitic magmatic source." I thought the most likely source of soda to be a migmatite, similar to those of Belmullet and Foxford in Ireland and Cromar and Glen Shee in Scotland, underlying the crestal area of the Cowal anticline.

On page $51 \mathrm{I}$ am quoted as an authority for the assertion that the albite schists are confined "to the Ben Ledi Grit Group, both in the present area and in the rest of the South West Highlands and Co. Mayo". On the contrary, I wrote: "In the Dalradian of North Mayo albite schists occur throughout a great thickness of Dalradian rocks whose correlation with the Standard Perthshire Succession is uncertain, but which are likely to lie below the Loch Tay Limestone, and possibly extend downwards as far as the Schiechallion Boulder Bed. There is no suggestion that in Mayo the albite schists are confined either to (i) Bed Ledi Grits or their equivalents, or (ii) rocks which may have contained abundant felspathic grits."

Dr. Jones fails to make clear where his views differ from mine, and does not in fact suggest any origin for the albite porphyroblasts, except to agree with Reynolds and myself that "sodium was introduced from an extraneous source by a large scale metasomatism ". He proposes, it is true, that " the formation of albite schists is an integral part of the regional metamorphism" but suggests that most of the soda " arose as the result of a late regional 
soda metasomatism ". This appears to be close to my own view, quoted by Dr. Jones, of a "late para-tectonic phase of metamorphism to some extent unconnected with the earlier regional metamorphism", which I followed with a proviso " that some influence on the metasomatic metamorphism is exerted by the regional metamorphism, which suggests that there is no great difference between the two phases".

My main reason for separating the late soda metasomatism from the main regional (zonal) metamorphism was the discordance between the albite and garnet " isograds". Dr. Jones apparently does not accept, as I did, the inversion of the zonal metamorphism in this area. The garnet isograd on his map (Text-fig. 1) indicates a near-vertical surface, since it crosses several deep valleys without deviation; the limit of albite porphyroblasts, on the other hand, is a gently curved surface following the predominant regional foliation-the Cowal anticline. For two manifestations of the same regional metamorphism to possess bounding surfaces intersecting at a high angle a considerable time gap seems to be necessary.

Perhaps it is mainly a question of nomenclature: how late must a soda metasomatism be before it ceases to be considered an integral part of the regional metamorphism? Further details will no doubt appear in the later publication to which Dr. Jones refers, including a suggestion, it is to be hoped, concerning the source of the soda; meanwhile there seems to be no significant difference between Dr. Jones' views and my own on the problems involved.

A. F. Trendall.

\section{Grological Survey Department,}

P.O. Box 9,

ENTEBBE, UGANDA.

25th April, 1961.

\section{REFERENCE}

Trendall, A. F., 1953. The Origin of Albite Gneisses. Ph.D. Thesis, University of Liverpool.

\section{REVIEW}

Edinburgh Geology, An Excursion Guide. Edited by G. H. Mitchell, E. K. Walton, Douglas Grant. $x v+222$ pp., 8 plates and numerous figures. Oliver and Boyd, Edinburgh and London. Price 12s. $6 d$.

This guide compiled and edited by Fellows of the Edinburgh Geological Society, describes twenty whole or half day excursions which can be made from Edinburgh. It includes much detailed local information about the Arenig to Upper Carboniferous stratigraphy and the wide range of igneous and glacial phenomena of the east and central parts of the Midland Valley and Southern Uplands. Understandably in a book of this scope, the only general attempt to synthesise the information is a brief introductory chapter. Some of the chapters include much unpublished material and all contain lists of references. In planning and carrying out field work, this little book will be invaluable not only to experienced geologists but also to those with less experience, for whom a glossary of terms and a table of mineral compositions are included. The maps, photographs, and general format are most attractive and the price seems remarkably low.

P. F. F. 